\title{
Strategies for the determination of the information requirements of an organization: a discussion
}

\author{
N.F. du Plooy \\ Department of Computer Science and Information Systems, University of South Africa, P.O. Box 392, Pretoria, 0001
}

\begin{abstract}
An attempt is made in this paper to clarify some of the ambiguities surrounding the topic of information requirements. Whereas current systems analysis practice is mainly concerned with determining the current and future information needs of the 'users' of the proposed information system, this study points out that the requirements process should begin much earlier - information requirements should indeed be derived from the overall strategic business plan of the organization. If an information system is to be successful over the longer term, it is not so much the needs of the user that should be determined, but rather the needs of the organization. For this purpose, strategic information system planning is indispensable. In effect this means that the development life-cycle of an information system starts earlier than indicated in current models. The consequences of this broader view of requirements definition for, inter alia, systems analysis are reviewed.
\end{abstract}

In hierdie artikel word 'n poging aangewend om sommige van die dubbelsinnighede betreffende inligtingsbehoeftebepaling op te los. Huidige stelselontledingspraktyk het hoofsaaklik te doen met die bepaling van die huidige en toekomstige inligtingsbehoeftes van die 'gebruikers' van die beoogde inligtingstelsel. Hierdie studie toon egter aan dat die behoeftebepalingsproses reeds veel vroeër begin, naamlik dat inligtingsbehoeftes afgelei behoort te word van die strategiese besigheidsplan van die organisasie. Vir inligtingstelsels wat oor die langtermyn suksesvol moet wees, is dit dus nie soseer die behoeftes van die gebruiker wat bepaal moet word nie, maar eerder die behoeftes van die organisasie. Vir hierdie doel is strategiese inligtingstelselbeplanning onontbeerlik. Verder beteken dit dat die ontwikkelingslewensiklus van 'n inligtingstelsel vroeër begin as wat tans in die tipiese modelle aangedui word. Die gevolge van hierdie breër siening van behoeftebepaling word, onder andere, vir die stelselontledingspraktyk bekyk.

\section{Introduction}

'An information system should meet the needs of the organisation it serves, and applications should meet the needs of their users' (Davis \& Olson, 1985: 474).

This statement appears self-evident. However, it has been documented over a considerable period of time and by numerous researchers and practitioners that the objectives expressed in it are difficult to achieve in practice (e.g. Lucas, 1975), (Munro, 1978), (Shemer, 1987), (Smith \& Wood, 1987:6), (Gilb, 1988:4).

The reasons for this lack of achievement are manifold. Much attention has been devoted over the past two decades improving the technical aspects of information system development, resulting in what became known as 'software engineering' which propounds a more rigorous approach to software development (Fairley, 1984). However, in spite of the real advances of software engineering, it was soon realized that a technically sound system is not necessarily the 'correct' system for the organization, since the following problems and deficiencies in information systems remain:

- Too much 'irrelevant' information still reaches managers at all levels (Rockart, 1979).

- Information systems prove inflexible and difficult to adapt to changing circumstances in the organization, to the extent that it has been reported that the majority of systems development undertaken was never completed, or if completed, never used (Lyytinen, 1987).

- Software, or the lack or failings thereof, is seen as an 'obstacle to industry growth' (Shemer, 1987).

- Users, at all levels, are still 'dissatisfied' with the results and performance of systems developed for them (Cooper \& Swanson, 1979), which led to the personal computer 'syndrome', leaving many organizations and information systems departments at a loss as to know how to deal with the sudden lack of control over 'personal' data processing (Henderson \& Treacy, 1986).

- Information systems managers are increasingly being made to account for their seemingly very costly departments, with lack of adequate performance (Sprague \& McNurlin, 1986: 43).

If we assume that the current state of the software design art is such that technically sound and efficient systems are being produced, what then is the reason or reasons for these problems? According to some authors (Cooper \& Swanson, 1979), (Shemer, 1987), (Smith \& Wood, 1987: preface) inadequate or incorrect requirements definition must be the major cause, since it is possibly the most difficult (Munro \& Davis, 1977) and also the most neglected feature of information systems design. It is during this phase of the 'life-cycle' of information systems development that the needs of the organization and the needs of the users have to be determined. If these needs are perceived incorrectly, the information system will not provide adequately for the information needs of its users, and it will therefore be regarded as less than successful, often as a failure (Lucas, 1975), (Munro \& Davis, 1977).

Writing on the importance of this phase of the development of an information system, Zmud points out that the relative cost of implementing a change during the requirements definition phase is a very small fraction of the cost of implementing changes at the later stages (1983: 307-308).

The importance of the requirements definition phase is further confirmed by the following statement resulting 
from an empirical study: 'The better adapted the definition of function requirements to organisational needs and the more explicit and complete the statement of requirements - the greater the likelihood of success' (Ein-dor \& Segev, 1981).

Requirements definition also has to do with the interaction of the information systems developers and the organization, which, apart from the technicalities involved, also concerns social and conceptual aspects of information systems. Lyytinen (1987) mentioned that it has been found repeatedly that most information systems problems relate to these aspects.

Why is the determination of requirements so problematical? Since its very beginnings, two major problems in information systems development have plagued the industry, namely that information systems developers do not know the organization well enough, and that users (or managers) are unable to express their needs and knowledge clearly enough (Ackoff, 1967), (Dearden, 1972), (Davis, 1979). This is the main reason why traditional methods of establishing the requirements of the organization and the users, that is, by asking selected managers and users about their information needs, have been less than successful in systems that are more complex than routine transaction processing.

In this article, strategies to determine and accurately map the needs of the organization and the needs of the users onto the information system will be discussed. The premise is that the former is the bigger problem, a problem that has often been neglected in favour of the second objective (the needs of the users), which are more closely related to the actual development process itself. It could be argued that concentrating on the second objective could lead to serious suboptimization of the information system, since the system which accurately reflects the needs of the users, is not necessarily the 'correct' system for the organization (Case, 1986: 33).

\section{The needs of the 'users'}

Textbooks agree that the purpose of an information system is to provide formal information to satisfy the needs of its users, be they managers or operational staff. The implication is that the 'needs' refer to information required to: '.....support operations, management and decision-making functions in an organisation' (Davis \& Olson, 1985: 6). (The term 'information system' is used here as a collective term to include what is often referred to as 'transaction processing systems', 'operational information systems', 'management information systems', 'executive information systems', 'decision support systems', etc., that is any computer-based system devised with the above-mentioned aims in mind.) Moreover, textbooks agree that requirements definition (or its synonyms such as requirements specification, original systems concept, systems definition, systems analysis, etc.) is that phase of the software life-cycle during which the needs of the users are determined (e.g. Burch, Strater \& Grudnitski, 1983: 21).

But who are the 'users'? Is it correct to say that the personnel of, for instance, the marketing division are the 'users' of the marketing information system? The implication is then that the marketing division does not 'own' the marketing information system. According to Lucas, the lack of ownership of the information contributes to uncertainty on the part of the user (Lucas, 1978: 61). It is possibly more correct to say that the personnel of the marketing division are 'members' of the marketing information system since they not only use, but also contribute to it. The real 'users' of the information system are top management (Smith, 1983: 14).

A major concern in focusing on the needs of the 'users' (in our terminology the 'members') during the requirements definition phase is that invariably the end result will reflect their current needs, expressed from their possibly restricted and subjective view of the organization. As early as 1970 Zani wrote: 'Rather than mirroring existing procedures, an information system should be designed to focus on the critical tasks and decisions made within an organisation....

It is therefore clear that we must distinguish between the needs of the members and the needs of the organization, since an information system which answers the needs of the members is not necessarily the 'best' system for the organization.

\section{The needs of the organization}

Determining the collective needs of top management, the real 'users', is the closest to determining the needs of the organization (Boynton \& Zmud, 1984), (Davis \& Olson, 1985: 460). What are the 'needs' of top management?

Obviously some of their needs are similar to those of the operational staff, namely information and tools (or means) to manipulate that information. However, this is not all that is required.

Sprague \& McNurlin (1986: 189) describe the information that managers need as follows:

- Comfort information, a term used for some of the daily figures regarding the state of the business, e.g. sales, that managers seldom act upon, but nevertheless want to receive.

- Problem information, that is, information concerning major crises or the progress of important projects.

- Information for outside dissemination, for instance to government, shareholders, or investment analysts.

- External intelligence, the much needed and much required information about the business environment, competitors, political evaluation, etc.

- Internal information about key performance areas of the organization.

This list illustrates that management information is very broad in scope, and that not nearly all of it is supplied from the traditional transaction processing systems. Note that the above-mentioned information could be supplied either formally or informally - the latter being rather difficult to formalize in data bases and files. 
In recent years, the needs of the organization have acquired a whole new dimension with the realization of the power of information systems and related technology as a competitive weapon. This means that the information systems must also satisfy the strategic needs of the organization (Mason, 1983; McFarlan, 1983; Ives \& Learmonth, 1984; Cash \& Konsynski, 1985; Henderson, Rockart \& Sifonis, 1987; Ghosbal \& Kim, 1986; Thompson \& Mead, 1988).

\section{Strategies for requirements definition}

Davis \& Olson (1985: 480) stated that there are four strategies for determining information requirements:

- asking;

- deriving from an existing information system;

- synthesising from characteristics of the utilising system; and

- discovering from experimentation with an evolving information system.

These strategies are equally applicable both to the determination of organizational information requirements and to application requirements. The strategies are not mutually exclusive, and could be used as applicable in different parts of the investigation process.

Each of these classes will now be discussed, bearing in mind their applicability as regards satisfying the organization's information requirements.

\section{Asking}

Asking is the time-honoured manner in which the systems analyst gathers information about the requirements of the members of the proposed system (Burch, et al., 1983: 310). Interviewing and recording the facts from the interview are often the only methods employed by systems analysts.

Asking is also employed to elicit the information needs of managers (and therefore also of the organization) either individually or in groups ('brainstorming'). Various guidelines exist for the selection of which managers to interview, for instance on the basis of knowledge of the organization, their decision-making responsibility, their informal power base, or on the basis of the respect in which their opinions are held by management and other staff.

Popular approaches using the interviewing technique for obtaining the information requirements of the organization are Business Systems Planning (BSP) (IBM 1981), Critical Success Factors (CSP) (Rockart, 1979). End-Means Analysis (EMA) (Wetherbe \& Davis, 1985), or combinations thereof such as those used in Strategic Information Systems Planning (SISP) (Whitmore, 1988). The questions used (Davis \& Olson, 1985: 462) reflect different ways of thinking about requirements, namely:

- What problems do you have and what information is needed for solving them?

- What decisions do you make and what information do you need for decision making?
- What factors are critical to the success of your activity and what information do you need to achieve success in them or monitor progress?

- What are the outputs (the ends) from your activities and what information do you need to measure effectiveness in achieving the outputs?

- What resources are used in producing the outputs and what information is needed to measure efficiency in the use of the resources?

None of these questions can guarantee that a complete set of requirements will be forthcoming. In some cases all three approaches are used in the hope that this will result in a more complete picture.

The asking approach could well be called the 'traditional' way of determining information needs. Traditionally this approach required the analyst to ask the manager what information he currently receives and what information he would like to receive. This approach came to be known in the literature as the 'data analysis' approach as oppposed to the 'decision analysis' approach during which a model of each decision required of the manager is constructed in order to determine what information is required for it (Munro \& Davis, 1977), (Munro, 1978). In both approaches the analyst relies on the manager to express his own information requirements or decision responsibilities. However, since the requirements definition derived in this manner depends to a great extent on the systems analyst's understanding of the needs of the organization, any shortsightedness or misconceptions will go undetected (Shemer, 1987).

In the research documented above, the conclusion was that the data analysis approach is more suitable in situations that are well-understood, typically as the case will be in most transaction processing systems. Decision analysis, on the other hand, seemed more suited to situations where adequate data are not readily available, such as in the case of some decision support systems. However, both approaches suffer from the same disadvantage, namely that the information needs that are determined are the 'personal' needs of the user or manager, rather than the needs of the organization. This means that although a manager may find the information system highly supportive of his own requirements, the next manager may not find it so. This disadvantage will always be part of any 'asking' approach.

As can be gathered from the above, the success of this approach depends on the experience of the analyst and the communication skills of the interviewees. Furthermore, in search of completeness, a requirements definition based on interviewing could take a prohibitively long time to complete (Munro, 1978). The fact that an experienced analyst is required if satisfactory and complete answers are to be elicited, could make this approach less attractive to organizations lacking such resources and unwilling to call in outside consultants. 
As regards the interviewing approach as such, it has been stated that because of the limitations of human beings as information processors, asking managers to think about their information requirements may yield less than satisfactory results (Davis, 1979, Davis \& Olson, 1985: 474). The major deficiency seems to be that managers tend to focus on only a subset of their needs, typically the needs that currently concern them, and therefore this method is not deemed very successful in determining the 'future' or 'strategic' needs of the organization. Davis added that an analytical model of the organization would be useful as a framework within which to ask questions in order to overcome the limitations of this method.

\section{Deriving from an existing information system}

According to Davis \& Olson (1985: 482) an existing system that has been in use for some time, whether in the organization or in another similar organization, or a clear description of such a system from manuals or textbooks, can be used to derive requirements for a proposed information system.

This approach could be restrictive in the sense that users and analysts would tend to base their requirements only on what they know of, understand about or see in the existing system. It is probably applicable in the case of operational information systems where fairly standard information outputs are required. It would not work as well when the requirements for strategic information systems or systems aimed at providing the organization with some competitive advantage, have to be determined (Ives \& Learmonth, 1984).

\section{Synthesis from characteristics of the utilizing system}

This approach suggests that the information requirements of both the members and the organization are best determined by studying the organization itself. In doing so, it hopes to remove bias or semantic difficulties introduced by the individual member or analyst. Furthermore, this approach supports the view that information systems should be planned in a topdown fashion, rather than evolving from the bottom upwards in an ongoing cycle of improvements to current systems (Zani, 1970), (King, 1978).

Various methods follow this general approach. In some cases (e.g. BSP, BIAIT) the internal business structures and resources of the organization are analysed in order to determine the requirements for the eventual information systems. King (1978) proposed a methodology called 'strategy set transformation' in which the information requirements of the organization are deduced from the mission and objectives of the organization. Rockart (1979) and others propose that the information requirements of chief executive officers (in other words, of the organization) could be derived by determining and then analysing the factors critical to operating and managing the organization. Other methods focus on the products of the organization, the decisions taken at the various levels and functional entities within the organization, the data flow in the organization, etc. In all cases the premise is that analysis of the host organization, by one or more of the methods mentioned, will yield the requirements definition.

Most of the methods rely on interviewing as the main investigating technique. Although in some cases the interviewing is more structured than in the pure 'asking' approach discussed above, it still suffers from the weaknesses described earlier. Noticeable exceptions are BIAIT (Carlson, 1979) and its derivative BICS (Kerner, 1979).

Through a very simple mechanism, the BIAIT methodology builds a model of the organization based on a generic or 'standard industry' perspective.

From this an information model which is verifiable is automatically generated. Thus the information needs of all managers at all levels can be addressed. Therefore, instead of following a 'discovery' process as in all other cases, the method applied is a 'normative' one. Discovery processes are by nature suboptimal in the sense that, due to the heavy reliance on analysts, their completeness and correctness are unverifiable. They are, moreover, time and labour-intensive and tend to produce voluminous reports (which are static) as their main deliverable. Through the use of a generic model, BIAIT and BICS aim at bridging the communication gap between management and analyst.

Finally, it is important to note that this approach is more likely to yield strategic information needs than any of the others discussed so far, since the model of the organization could be manipulated to include 'what if' planning scenarios, together with their associated information flows. It is thus very applicable in establishing the requirements of the organization.

\section{Discovering from experimentation with an evolving information system}

In the approaches discussed so far, the objective has been to establish a complete set of information requirements before the system is designed and implemented. In this approach that is not the case. A 'prototype' or experimental system is designed and built quickly according to requirements determined after a relatively superficial investigation. The rationale has already been established in the earlier sections, namely that users are not able to provide complete requirements definitions. Therefore, this approach proposes a partial solution, from which users may find it easier to formulate the final requirements as they visualize that system from the experience of using the prototype (Gilb, 1988).

Evolutionary development of information systems was made viable by the introduction of the higher-level or 'fourth-generation' languages which enabled systems designers to create a prototype of a system in a much shorter time than was previously possible. Such systems were often created in close conjunction with the eventual users. In the course of time, certain definite disadvantages of the use of fourth generation languages became evident (Case, 1986: 153), but, with careful management of prototyping as a software engineering 
tool, most of these could be overcome. This approach made it possible to create systems that are easy to adapt and change as the requirements evolve.

Prototyping can significantly improve systems design in the sense that it allows the system to evolve to one that meets almost all of the needs of the user. However, the requirements that are mainly satisfied are the 'immediate' needs of the users. As a tool for determining the strategic requirements of the organization it has limited application.

\section{Conclusions}

Requirements definition is shown as the first phase in all the various current models employed to describe the lifecycle of a software product (Charette, 1986). However, it is quite clear from the literature and from current systems analysis methodologies that the activities of this phase are aimed at determining the information needs of the members rather than the real users, that is, top management. Information systems tend to grow from the bottom up, as and when new systems are required, often resulting in a patchwork or federation of interrelated systems. Furthermore, the information system department is expected to indicate the future technological road of the organization and is frequently in the position where they have to 'sell' their plans and products to other, often less than willing, members of the organization.

This situation stems from the above-mentioned narrow view of requirements determination. The most important question is whose needs are more important, those of the members or those of the organization? We have shown that these needs are not similar. Also, how can meaningful planning be done by the information systems department if they ignore (or are never asked to determine) the needs of the organization and only concentrate on the needs of the members? The narrow view of requirements determination will in most cases lead to systems that are, however well-designed and technically sound, not completely in step with the needs of the organization. This statement is especially true as regards the strategic needs of the organization.

The narrow view referred to above can be expanded by accepting that the life cycle of an information system starts earlier than the traditional phase of 'requirements definition'. The needs of the organization are derived from some or other strategic plan, whether formal or informally established. Without a link between the organization's strategic plan and the information systems plan, it is difficult if not impossible to build effective information systems, since the needs of the organization are not known. This is in accordance with the earlier views of Zani who presented a framework that assumes that top management itself must start the design process by delineating the organization's strategy structure and decision-making processes (Zani, 1970). According to Zani, an effective system can only be born of a carefully planned rational design that looks down from the top, the natural vantage point of the managers who will use it.
Therefore, as the first conclusion of this study, we propose that the life-cycle of an information system should have as its first phase the establishing of a strategic direction for the organization as a whole. The next step in this phase should be to link that strategy to the information systems plan (Mason, 1983), (McFarlan, 1983), (Venkatraman, 1985), (Tozer, 1986), (Henderson, et al., 1987). This initial phase of the life cycle has been called 'enterprise analysis' (Edwards, 1985), (Davis \& Olson, 1985). Requirements definition cannot be attempted if strategic needs are not taken into account. This holds true even if many transaction processing systems are already in place. The importance of this step, and the linking of the organization's strategy to the information systems plan, cannot be overemphasized.

It has been recognized that it is difficult to link the organization's strategic plan to its information systems plan. Henderson, et al., (1987) extended previous work on the use of critical success factors as a base for a strategic planning approach from which the information needs for executive information systems, management information systems, and decision support systems could be derived. The need for a better methodology than the interviewing technique most often used today, has also been made abundantly clear by them (see also the third conclusion below).

However, systems analysts are typically not trained to determine the needs of the organization. A reason for this is the current fragmentation of the job of the systems analyst. As the name implies, a systems analyst is someone who analyses 'systems'. Contrary to popular opinion, a new computer-based system is not what should be inferred by this term. The 'system' referred to is, at the very least, the whole organization, of which the computer-based systems are but subsystems. Concurring with Shemer (1987) we deplore the fact that current systems analysts seem to be unaware of the excellent framework supplied by the systems approach (e.g. Beishon \& Peters, 1972), (Weinberg, 1975). Without this framework, systems analysts tend to concentrate on the technical aspects of their work, leading inevitably to their taking only the needs of the members into account. The context of the new information system that they are to produce is ignored, thereby leading to the production of suboptimal systems (see also Freeman, 1981). It should be realized that systems analysis deals not only with the 'solution', but also with the problem domain. Therefore, education and training courses for systems analysts should emphasize the word 'system' in its broadest sense and should preferably begin with a discussion of general systems theory.

Thirdly, Davis (1982) noted that the simple timehonoured strategy of asking the 'users' to describe their requirements for an information system may not be adequate. This is corroborated by the abundance of requirements specification methodologies and development approaches that have been proposed for requirements definition over the last two decades (see Shemer, 1987 for a comprehensive list of references). In most cases these methodologies still use 'asking' as their 
major technique, especially at the beginning of the investigating process. As indicated by Davis, 'asking' is appropriate in instances where the application area is well-known. In the case of strategic information systems, however, the limitations of this approach will seriously hamper the systems analyst in determining the information requirements. A modelling approach such as the one used by the BIAIT methodology avoids the subjectiveness and other shortcomings of the 'asking' approach. It also obviates the need to rely on outside consultants or, at the very least, on an experienced analyst for strategic information systems planning.

Fourthly, organizations must be warned against adopting a single development methodology to be used in all applications. Even though it might be simpler and less expensive to do so, it is clear that some methodologies are more useful and give more complete results under particular circumstances than others. Davis \& Olson $(1985 ; 493)$ discuss various approaches to selecting a strategy for determining requirements. They suggest that the strategy should be determined by the characteristics of the organization, much the same as saying that the systems analyst should take the 'problem space' into account as a serious factor. In essence this result also advocates and supports the view that systems analysis should be practised in the broader context outlined above.

Finally, it must also be realized that since an organization is an open system it is also dynamic and changes over time, in some cases quite rapidly. It is therefore not possible to state at any one time that the requirements definition is complete and comprehensive. The best that a systems analyst can aim at is to determine the needs of the organization as they are perceived at that point in time, and, aided by the strategic vision of management, to anticipate such needs as will be forthcoming as the strategic plans develop. It is not sufficient to stop at current needs - strategic plans must be taken into account. However, the systems which are designed on the strength of these requirements must be flexible so that they can be adapted to changed circumstances.

\section{Acknowledgement}

This paper has benefited from discussions with Johan Smith and Rene Jacobs.

\section{References}

Ackoff, R.L. 1967. Management misinformation systems. Manage. Sci., vol.14, B147-156.

Beishon, J. \& Peters, G. 1972. Systems behaviour. London: Harper \& Row.

BIAIT. A simplified view of the methodology known as Business Information Analysis and Integration Technique. BIAIT Systems Europe Ltd.

Boynton, A.C. \& Zmud, R.W. 1984. An assessment of critical success factors, Sloan manage. Rev., Summer, 17-27.

Burch, J.G., Strater, F.R. \& Grudnitski, G. 1983. Information systems: theory and practice. John Wiley, New York.
Carlson, W.M. 1979. Business information analysis and integration technique (BIAIT) - a new horizon. Data Base, Spring, 3-9.

Case, A.F. 1986. Information systems development: principles of computer-aided software engineering. Prentice-Hall, Englewood Cliffs.

Cash, J.I. \& Konsynski, B.R. 1985. IS redraws competitive boundaries, Harv. Bus. Rev., March-April 1985, 134-142.

Charette, R.N. 1986. Software engineering environments. McGraw-Hill, New York.

Cooper, R.B. \& Swanson, E.B. 1979. Management information requirements assessment: the state of the art, Data Base, Fall, 5-15.

Davis, G.B. 1979. Comments on critical success factors method for obtaining management information requirements . In: Rockart, J.F. MIS Quart., vol.3, September, 57-58.

Davis, G.B. 1982. Strategies for information requirements determination. IBM Systems J., vol.21, 4-30.

Davis, G.B. \& Olson, M.H. 1985. Management information systems 2nd Edition, McGraw-Hill, New York.

Dearden, J. 1972. MIS is a mirage. Harv, Bus. Rev., vol.50, 90-99.

Edwards, D.A. 1985. Tools for the analysis of and for the structure of enterprise wide information systems. Unpublished paper, BIAIT Sytems, Inc., Toronto.

Ein-dor, P. \& Segev, E. 1981. Paradigm for management information systems. New York: Praeger.

Fairley, R. 1984. Software engineering concepts New York: Mcraw-Hill.

Freeman, P. 1981. Why Johnny can't analyze. In: Systems analysis and design: a foundation for the 1980's. Cotterman, W.W. et al. (Eds.), North Holland, Amsterdam.

Gilb, T. 1988. Principles of software engineering management, Addison-Wesley.

Ghosbal, S. \& Kim, S.K. 1986. Building effective intelligence systems for competitive advantage. Sloan Manage. Rev., Fall, 49-58.

Henderson, J.C. \& Treacy, M.E. 1986. Managing end-user computing for competitive advantage. Sloan Manage. Rev., winter, 3-14.

Henderson, J.C., Rockart, J.F. \& Sifonis, J.G. 1987. Integrating management support systems into strategic information systems planning. J. Manage. Inf. Systems, vol. 4, summer, 5-24.

IBM 1981. Business systems planning - Information systems planning guide. Application Manual GE20-0527-3, 3rd Edition, Ibm Corporation, July 1981.

Ives, B. \& Learmonth, G.P. 1984. The information system as a competitive weapon. Communications of the $A M C$, vol.27, 1193-1201.

Kerner, D.V. 1979. Business information characterization study. Data Base, Spring, 11-17.

King, W.R. 1978. Strategic planning for management information systems. MIS Quart., vol.2, March, 27-37.

Lucas, H.C. 1975. Why information systems fail. New York: Colombia University Press.

Lucas, H.C. 1978. Information systems concepts for management. New York: McGraw-Hill, p.61.

Lyytinen, K. 1987. Different perspectives on information 
systems: problems and solutions. ACM Comp. Surveys, vol. 19, March, 5-45.

Mason, R.O. 1983. Information systems strategy and corporate strategy. Harvard Business School.

McFarlan, F.W. 1983. Linking I-S strategy - corporate strategy. Harvard Business School.

Munro, M.C. \& Davis, G.B. 1977. Determining management information needs: a comparison of methods. MIS Quart., vol.1, June, 55-67.

Munro, M.C. 1978. Determining the manager's information needs. J. Systems Manage, June, 35-39.

Rockart, J.F. 1979. Chief executives define their own data needs. Harv. Bus. Rev., vol. 57, 81-93.

Schemer, 1. 1987. Systems analysis: a systemic analysis of a conceptual model. Comm. ACM, vol.30, June, 506-512.

Smith, D.J. \& Wood, K.B. 1987. Engineering quality software. London: Elsevier Applied Science,p.21.

Smith, A.J. 1983. An examination of the leadership role of the information systems developer. Unpublished M.Sc. thesis, University of South Africa, Pretoria.

Sprague, R.H. \& McNurlin, B.C. 1986. Information sysytems management in practice. Prentice/Hall Int.
Thompson, J.M. \& Mead, K.C. 1988. Boost your market power with information technology. Indications, The Index Group, vol.5, March/April.

Tozer, E.E. 1986. Developing strategies for management information systems. Long Range Planning, vol. 19, 31-40.

Venkatraman, N. 1985. Research on MIS planning: some guidelines from strategic planning research. J. Man. Inf. Sys., vol.11, Winter, 65-77.

Wetherbe, J.C. \& Davis, G.B. 1985. Strategic MIS planning through end-means analysis. University of Minnesota, MISRC working paper series quoted in Davis \& Olson (1985).

Weinberg, G. 1975. An introduction to General Systems Theory. New York: John Wiley.

Whitmore, P. 1988. Strategic Information Systems Planning workshop manual. Randburg: Whitehead Morris.

Zani, W.M. 1970. Blueprint for MIS. Harv. Bus. Rev., vol.46, 95-100.

Zmud, R.W. 1983. Information systems in organisations. Illinois: Scott, Foresman and Co., Glenview. 